(C) IPA, 2006 - Proceedings of an International Conference on Petroleum Systems of SE Asia and Australasia, 1997

IPA97 - PO - 21

INDONESIAN PETROLEUM ASSOCIATION

Proceedings of the Petroleum Systems of SE Asia and Australasia Conference, May 1997

\title{
THE INTERACTION OF TECTONICS AND DEPOSITIONAL SYSTEMS ON THE STRATIGRAPHY OF THE ACTIVE TERTIARY DELTAIC SHELF MARGIN OF BRUNEI DARUSSALAM
}

\author{
Paul Crevello* \\ Chris Morley* \\ Joseph Lambiase* \\ Mike Simmons**
}

\begin{abstract}
The late Tertiary stratigraphy of Brunei Darussalam comprises a series of seaward younging synclinal basins, bordered by N-S fault trends and shale diapirs. More than $15 \mathrm{~km}$ of deltaic marine sandstone and shale were deposited in migrating depocenters. The sediments were derived from the nearby uplifted Crocker-Rajang accretionary range. The migrating depocenters are exposed in outcrop in the onshore region and occur in a variety of fault-bounded basins in the offshore, where they produce hydrocarbons. The onshore district consists of at least three synclinal basins, two of which extend offshore. The offshore district consists of an inner eastern belt of counterregional (shoreward-dipping), fault-bounded, synclinal basins and an outer western belt of seaward-dipping regional growth faults and diapirs. The near offshore inner belt is continuous with the onshore basins.
\end{abstract}

The geology of the onshore basins is well exposed in outcropping Miocene strata. These strata produce from onshore and offshore fields, as well as provide exploration- and reservoir-scale analogs for younger Tertiary strata that occur in the offshore district. The surface geology records syntectonic stratigraphic relationships that are apparent in seismic data from the offshore district. The outcrop data provide highresolution stratigraphic correlations which are below 3-D seismic and well resolution, which is important for improving reservoir definition. Syntectonic stratigraphic features include shelfal and turbiditic growth fault sub-basins, inverted structures (shale

* University of Brunei Darussalam

** Aberdeen University diapirs and anticlines), angular unconformities proximal to inverted structures which record tectonically induced base-level control on stratigraphy, exotic structural blocks, and coarse conglomeratic beds.

Rigorous documentation of the onshore geology combined with studies of high-resolution offshore data sets will result in better exploration concepts, especially for subtle syntectonic/stratigraphic bypass zones, and result in more cost-efficient reservoir exploitation.

Onshore and offshore production is from sandstone of tidal, deltaic, and shoreface strata in various types of syntectonic and post-depositional structures (James et al, 1984; Sandal et al., 1997). The region was dominated by at least three delta complexes that shifted across Brunei during the Late Tertiary, marked by progressive basin fill as deltaic depocenters migrated seaward (Sandal et al., 1997).

The first geologic study published on the onshore and offshore districts of Brunei was compiled from Brunei Shell Petroleum projects (James et al, 1984), which recently has been revised (Sandal et al, 1997). These studies deal with various aspects of the hydrocarbon habitat of Brunei, with updated information on subsurface tectonics and stratigraphy in the latter report. Absent in these studies is a documentation and integration of the outcrop geology into syntectonic and stratigraphic models.

The onshore geology of Brunei records syntectonic stratigraphic relationships that demonstrate contemporaneous growth of basins and deposition of 
tidal deltaic and shoreface strata. Observations made from the onshore geology provide constraints for reservoir- and sub-basin-scale stratigraphic relationships. The offshore data provide regional observations for large-scale structural and stratigraphic relationships, with less constraints for reservoir-scale features. Together, study of the onshore and offshore provide important analogs for improving the understanding of reservoir distribution and trapping. The objective of this study is to provide a status report of the work being carried out by the Unversity of Brunei Darussalam tectonic and stratigraphic research groups. A location map and summary of the geology are presented in Figures 1-4. This study presents the first documentation of the syntectonic stratigraphy of the onshore region and relationships with the offshore districts.

James, D.M.D., 1984, The Geology and Hydrocarbon Resources of Negara Brunei Darussalam (editor); Muzium Brunei, 1984.

Sandal, S.T., 1997, The Geology and Hydrocarbon Resources of Negara Brunei Darussalam (editor); Revised Edition 1996. 


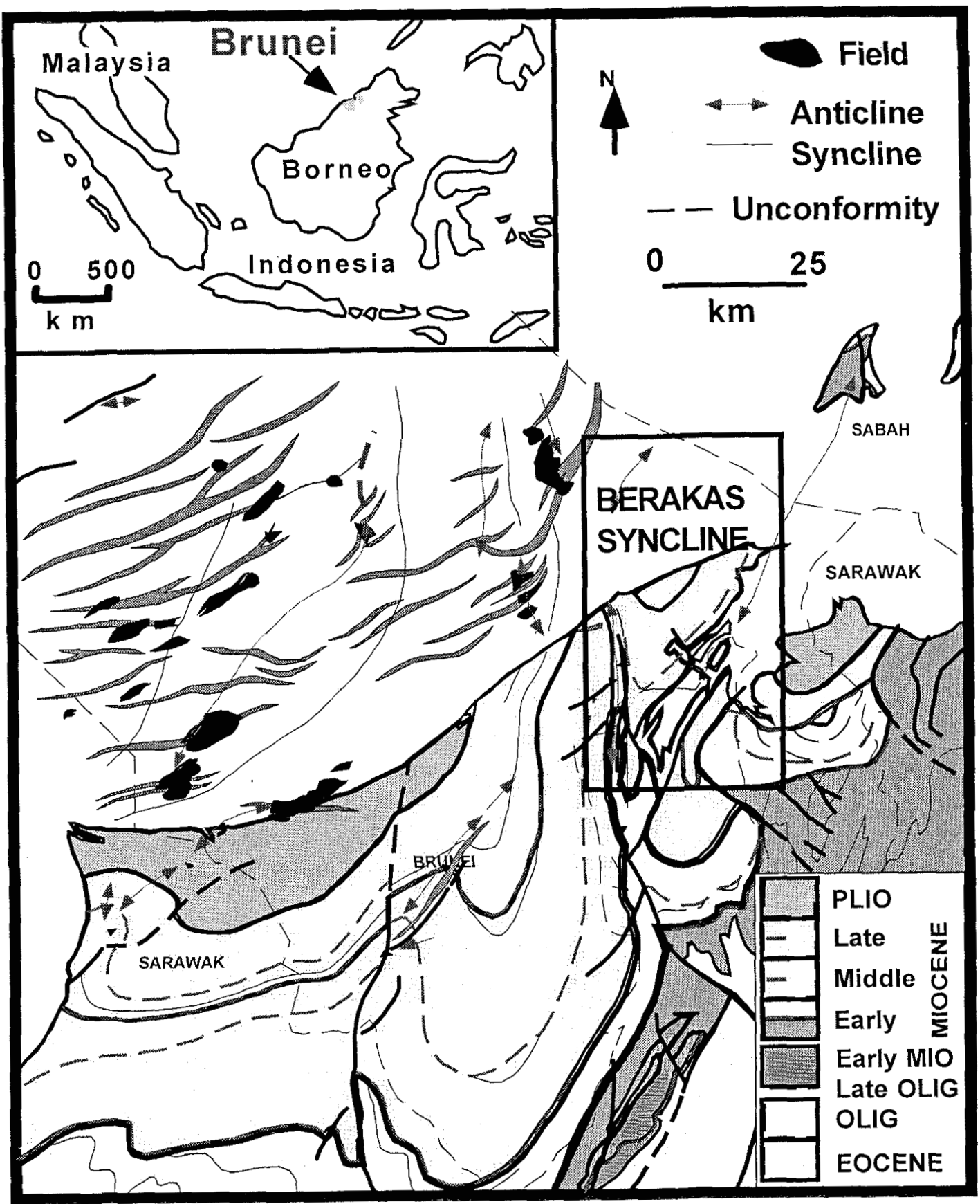

FIGURE 1 - Geology of the onshore and offshore region of Brunei Darussalam and adjacent Malaysia with the location of Berakas Syncline (modified after James et. al, 1984). 


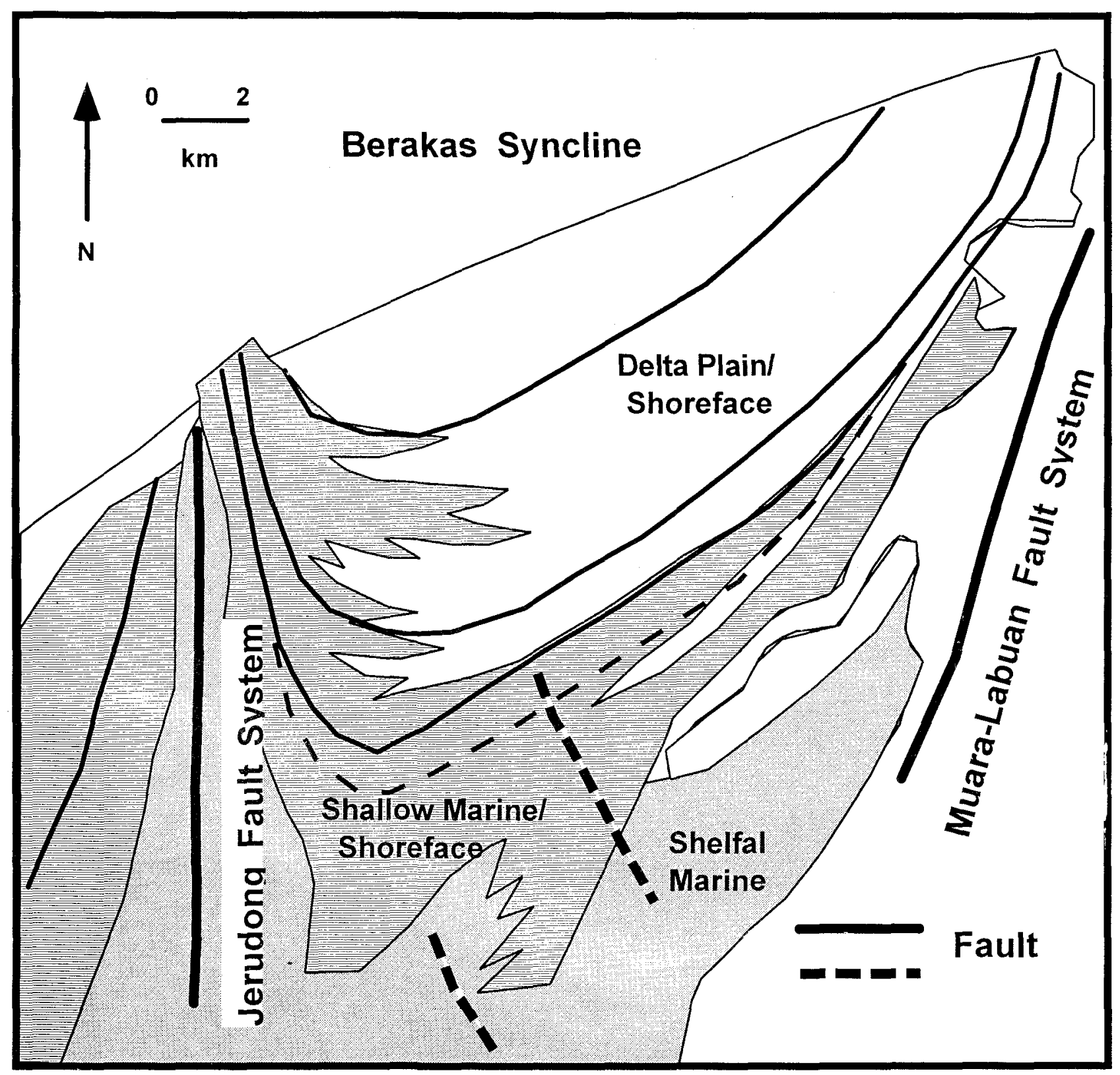

FIGURE 2 - Geology of the Berakas Syncline bounded by the Jerudong and Muara-Labuan Fault systems. Inferred growth faults are shown with dashed lines in the early part of the basin. 'Setap' Shale underlines the basin while shallow-marine tidal shoreface and shelfal strata pass laterally to the northeast to predominately shoreface to tidal and deltaic strata. Tidal and deltaic shoreface para-sequences dominate the stratigraphy in the basin. Stratal bedding trends are shown as curved lines in syncline; dashed curved line approximates the Minturi unconformity. 


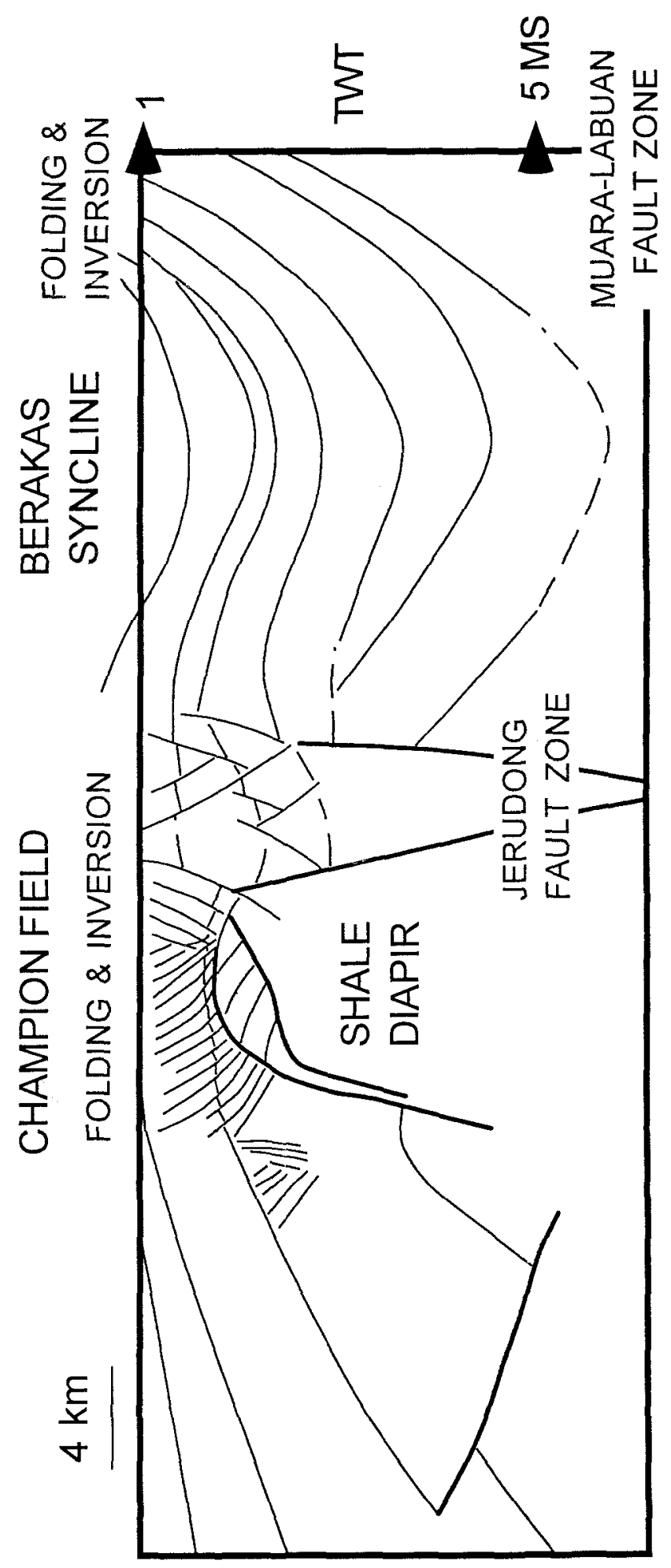

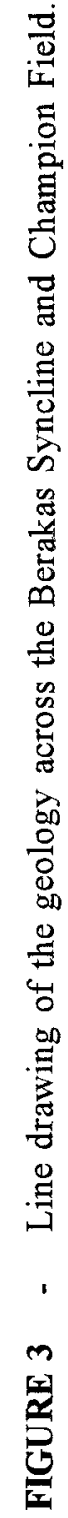




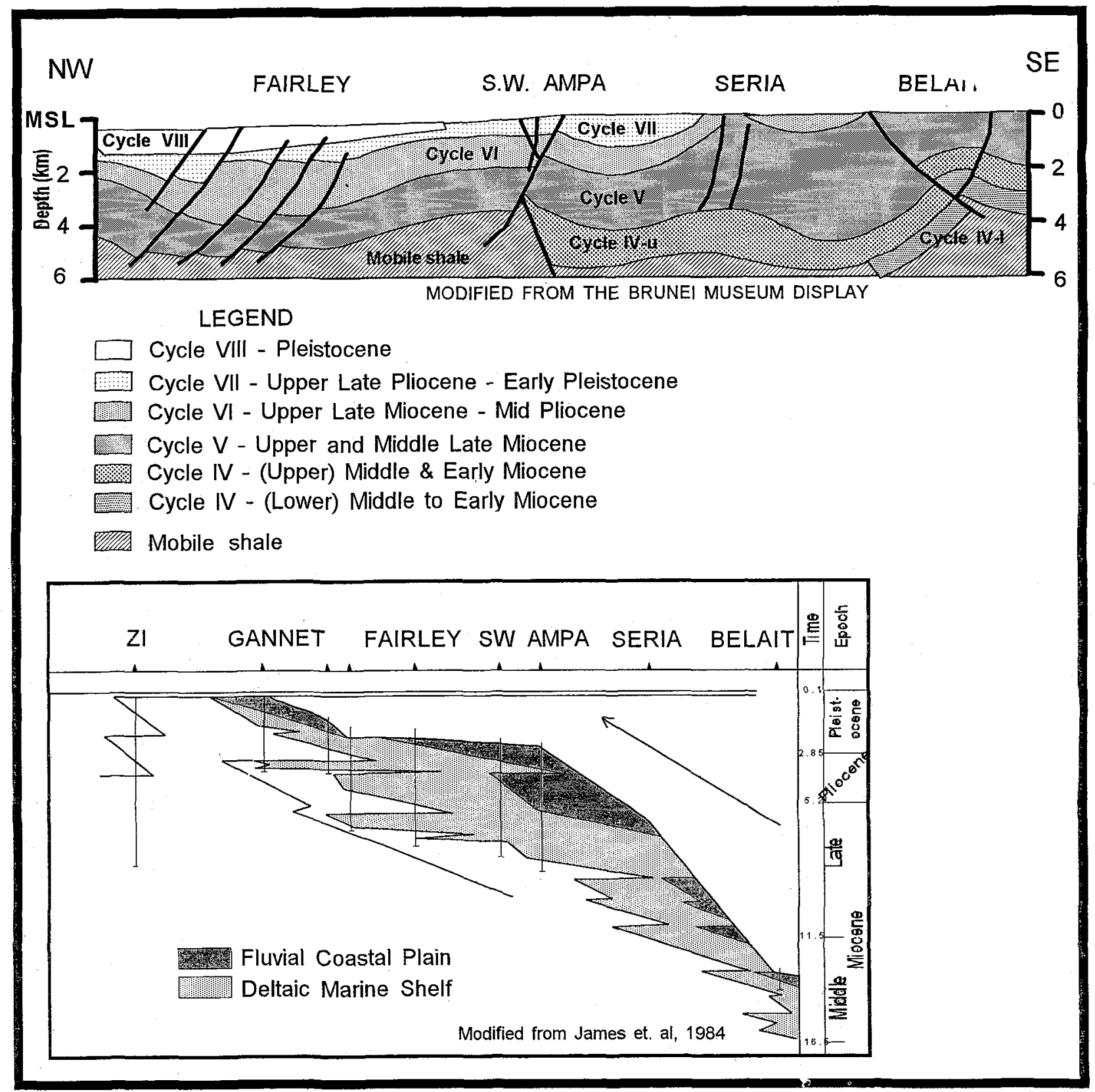

FIGURE 4 - Line drawing of the geology of onshore Belait Syncline to offshore across Ampa Field (modified after Brunei Museum display and from James et. al, 1984). Note the progressive inboard uplift of the onshore basins and seaward younging of offshore basins. 